\title{
The Challenges and Transformation of Design Education in Contemporary China
}

\author{
Dr. Peipei $\mathrm{Yu}^{1}$ and Prof. Bob Jerrard ${ }^{2}$ \\ ${ }^{1}$ Researcher, Faculty of Art, Design and Media, Birmingham City University, Birmingham, United Kingdom B4 7RJ \\ ${ }^{2}$ Emeritus Professor of Design Studies, Faculty of Art, Design and Media, Birmingham City University, Birmingham, United Kingdom \\ B4 7RJ
}

\begin{abstract}
This paper explores, through comprehensive perspectives, the challenges of the current design education system in China under the contemporary context. The influences that have transformed design in China from both historical and contemporary context are described mainly from literature. Interview data from professors from various design institutions and senior designers in companies in China were analysed to provide differing perspectives. The research findings show the inter-relationship between the various cultural and historical influences on Chinese design education. The authors conclude on how education might benefit from concentrating on this inter-relationship.
\end{abstract}

\section{Introduction}

The opening-up policy of China from its closed-doors brought in a new and exciting world of culture, including design predominantly from the West. China has changed dramatically in recent decades, from the conservative communism that restricted markets, to the open-door policy in 1980s which saw an aggressive adoption of capitalism within the communist ideology [1]. China is currently the most populous country in the world and the world's second largest economy after the United States [2]. The 'opening-up' policy introduced in the 1980's saw an acceleration in the Chinese economy, with vast job creation and high levels of migration to major cities. In the past 30 years, 300 million people have been urbanised, while, it is estimated that by 2026, a total of 500 million people will be classed as the middle class - creating a rapid growth in demand for consumer goods [3]. According to the research of Woetzel and Towson [4], professors at Peking University's Guanghua School of Management, China's strong consumer market will continue to surprise the world with its market growth, which is the fastest compared with any other countries in the world [5], along with the greatest potential amongst emerging economies to be the next economic superpower.

However, despite the presence of a flourishing economy, design education in China has not followed through in its development in comparison to the country's economy. In an increasingly globalised economy, the financial, cultural and consumer ideals of the West have become widespread. China, alongside most of the developing world, has since been consuming and adapting to the culture-specific products that consist mainly of what [6] named "English language centric products". With increasing Western influence in a growing Chinese economy, various imitation products have created a new trend - a shanzhai (imitation) phenomenon in product designing which has flourished amongst an upcoming society; individuals have a growing income alongside an increasing demand for products associated with a certain economic status. However, such aspiration is not only present in industry, but also in design education - which traces back to the philosophy and socio-economic situation of imperial China. This paper will address the origins of product design through its historical contexts in China. It also constructs a justification for the transformation of product design in China by linking such contexts with more recent mechanised and informational periods. The existing educational perspective in design is described from interviews with designers and professors from design institutions in China. Cultural originality with regards to the Western influence on product design development in China is also described.

\section{Desig4n Origin and Transformation in China}

According to Pevsner [7] the concept of design originated from the thinking of William Morris (1834-1896), the leader of Arts and Crafts Movement, and John Ruskin (1819-1900), a leading English art critic of the Victorian era. Both men advocated the concept of artisan craftsmanship, and placed an importance on aesthetics in response to the mechanical production of goods during the Industrial Revolution, which produced items that lacked design creativity and principles [8] More recently, China has also seen the growth of industrialisation and the significant growth of mass-produced goods. The development of Chinese industries from a product design history can be seen in the four periods addressed [9]: a) 
the emergence of heavy industry through the Westernisation Movement from 1860 to 1911 ; b) the DEVELOPMENT and formation of modern industrial structures post-revolution from 1911 to 1927; c) the rise of the Kuomintang Government, which gave way to increased development of industries from 1927 to 1937; and d), the formation of the People's Republic of China, which then saw a rapid increase in domestic industries within China from 1937 to 1949. The industrial periods from 1860 to 1937, which are now seen as the beginnings of industrialisation in China, were greatly influenced by Western technology with a similar emphasis on the mechanical production of the Industrial Revolution. In the wake of the revival of Chinese industries, there were nationalistic sentiments to resist the 'invasion' of Western influences, which encouraged the Chinese to learn advanced Western science and technology, as well as social management systems for appropriated use [10] which at that time was deemed more effective and developed. The nationalistic sentiment also led to the boycotting of foreign goods in the early 1900s, including those from Japan and Germany. This allowed local manufacturers to promote domestic products and revive Chinese manufacturing through patriotic motivation [11]. However, due to China's boycotting of foreign influence, the development of technologies in product design and manufacturing lagged severely behind the West, its severity highlighted especially during the Cultural Revolution in the 1970s. As described by Chen and Tang [12], China was losing out not only through its industrial immaturity and lack of technical know-how, but also through the development and understanding of modern design ideology linked to cultural awareness during the period of industrialisation. Henceforth, it is to be deduced that the backwardness of Chinese industrialisation in the period of rapid global industrialisation has resulted in the deficiency in maturity and originality of Chinese contemporary product design. As evidenced by Ling [13], the Chinese business communities, which started manufacturing products through varying degrees of acquired Western technology and knowledge, struggled with the appropriate technical capacity and know-how to produced quality Chinese goods.

The conceptualisation of 'design' is not of Chinese descent, product design has a Western origin, which, through cultural influence, made its way to the East. Also, the on-going 'idea' of design was largely attributed as a Western ideology [14], which saw its embryonic beginnings in the Industrial Revolution and underwent a century of maturing through the post-industrial age of mass production [15]. Morris and Kwok [16] provide a context for researching Chinese product design originality suggesting that product design was brought into China mainly through trade, following the Chinese open-door policy of the 1980s [17]. Indeed, understanding product design as an industry in China has a history of only 30 years, and the similarity and obvious lack or originality of Chinese product design over the last three decades, can be explained by these early Western influences. The pioneer educators of product design in Chinese universities were also influenced by Western design methodology, introduced by academic colleagues with a Western design education.

\section{The Challenges of Design Education in China}

The teaching of product design ideas and philosophy was introduced by Western countries to China [18]. Such education played a significant role in transferring the concept and idea of design to a younger Chinese generation, in order to produce designers for contemporary society in China. In order to bring Chinese cultural brands to a global audience, it is essential that the educators share but also adapt the same concept and idea in order to guide students. At the beginning of the 1980s, many universities - such as the Academy of Art and Design, at Tsinghua University (1984), and the School of Design, Hunan University (1982) - pioneered the industrial design education in China. All of the course founders studied design in various Western countries for many years in order to observe the Western teaching system [19]. Over the next four decades, the Chinese design education system continued to develop, based upon the Western teaching structure[14]. Given the high demand, Chinese design education has grown significantly in recent years and the number of universities which have design courses has exceeded 1,000 . When interviewed, [20] stated that there are around 700 universities which offer industrial design and 100 or more students graduate from different universities each year. However, [20] also indicated that most courses operate at a basic level of industrial design understanding, and because of limited faculty resources and the education system of some universities, the capability to conduct high quality design projects cannot currently be achieved.

At present, the design education systems in various Chinese universities have similar features, in that they have a large student numbers; some course structures and teaching outcomes are indistinct; most of institutions focus is on design skills rather than research and creative ability [21]. To some degree, those issues limit the comprehensive development of the students. Such discrepancies could be attributed to the universities literally following other countries' design progress, whilst ignoring the indigenous design quality and cultural values of Chinese products. [19] concluded that the teaching of product design in China typically falls into a three-phase teaching form: a) modelling foundation, b) specialty foundation and c), professional design. The challenges for the design educators in China are the internal connection between these phases; a systematic teaching model could be formed and achieved, although the provision of comprehensive training skills also falls short. The long term goal must be to expand the education foundation and cultivate inter-disciplinary talents applicable to the requirements of the time [22].

\section{Research Findings}

Based on the interviews conducted with educators of product design in a number of Chinese universities as part 
of this paper, findings have suggested that education is an important factor in the design development in China. Evidence from literature also suggests that educators brought the teaching ethos on design from the West [14] back to China in the 1980's [18], when the country was facing a healthy economy with high demand for production from both within and outside China. Due to the Westernised approach in design education, highlighted in the aspects of concept cultivation, education model and teaching methodology - students in China graduating from these institutions would naturally be equipped with a Western design inclination rather than one of Chinese origins.

Based on the authors' literature review of the design industry, it is suggested that design companies have also contributed to the lack of originality in contemporary Chinese product design. Design companies in China have rushed to produce imitated goods to capitalise on the Chinese consumers' appetite for branded products [23] [24]. From the authors interviews of Chinese design professionals, design companies seek quick and instant profits, focusing their efforts on marketing, rapid production chain expansion and technical replication accuracy. Instead of investing in original design, they have often focussed on the imitation of branded goods to satisfy the growing domestic demand for cheaper alternatives to Western products that are overly expensive compared to the average income of a Chinese consumer [25]. The Westernisation of designing in design companies is also interlinked with the education of graduates, as design companies employ young graduates with little or no fieldwork experience [26] but who have been Westernised in their design inclination and preference, leading to a further lack of Chinese cultural originality in Chinese contemporary product design.

\section{Discussion}

Combining the findings from literature on Chinese contemporary product design with the interview findings conducted with scholars and practitioners from the product design education and industry, this study proposed an inter-relationship between the various factors influncing the cultural originality in Chinese contemporary design, as illustrated in Figure 1.

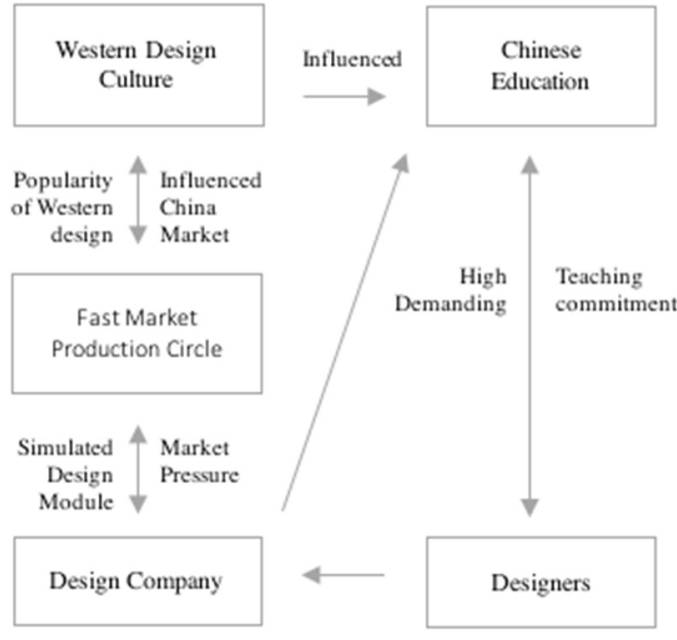

Figure 1. The inter-relationship in China influenced by Western culture

There are strong connections between each section. Western design culture has been influencing Chinese design since the industrial age, leading to the importing of Western technological and design educational learning into China. This leads to a Westernised approach in teaching and, hence, the professional development of Chinese designers with a lack of originality in their design thinking. These graduating designers either formed their own company or worked for other Chinese companies that fed into the growing Chinese market. A market which, in it's current state of rapid growth, demands globally popular and mature Western products. The interrelationships between all these factors have caused the lack of cultural originality in contemporary Chinese products. The outcomes of the complex interrelationships point to several new factors influencing Chinese design creativity and originality. The combined imitation phenomenon could be acknowledged as the inevitable outcome during the design development of a growing economy such as China.

\section{Conclusions}

A fusion of Chinese and Western elements might be the new way to innovate in the use of ancient Chinese elements, and may improve the creative skills as a soft power, assisting the national brand in the eyes of the world and rebuilding national confidence in contemporary design. Economic globalisation inevitably cause great friction with different cultures. Whether it is the eastward transmission of Western sciences, or the dissemination of Oriental learning, different cultures still retain their respective characteristics while seeking mutual recognition [27]. Design thinking is able to uniquely bring together differing cultural knowledge and experiences, hence from a educaiton perspective, the institutions should adopt the attitude of respect towards cultural depths and differences in their designing process. Manifesting Chinese traditional elements in contemporary design appears initially successful. Students should have a profound confidence coupled with a good understanding of Chinese traditional culture in 
order to incorporate Chineseness in various ways. In the globalisation context, it is necessary to seek plenty of methods to properly integrate into modern product design.

Design education is one of the most signification factors in design development of contemporary China and it is the main method of imparting the importance of important cultural values in design, given that university education is the primary way to inspire potential designers. Therefore, the teaching of design in China and the methodology of training needs to be rethink if the aim is to cultivate more culturally original designers.

\section{References}

1. J. Diamond, J. Liu. China's environment in a globalizing world. Nature. 435.7046. (2005)

2. D. Barboza, China passes Japan as second-largest economy. The New York Times. 15. (2010)

3. X. Liu, Y. Li and F. Feng. Thirty Years of Legal Theory China's Reform and Opening up: 1978-2008 Law and Social Development. 5. 003. (2008)

4. J. Woetzel, J. Towson. The One Hour China Book: Two Peking University Professors Cayman Islands, Towson Group (2008)

5. Z. Ma, M. Yu, C. Gao, J. Zhou, Z. Yang. Institutional constraints of product innovation in China: Evidence from international joint ventures. Journal of Business Research. 68. (2015)

6. P. M. Sathikh, S. Kumar. Culture in Transition - How 'global products' are changing user behavior. Faculty of Engineering National University of Singapore. (2009)

7. N. Pevsner, Pioneers of Modern Design: From William Morris to Walter Gropius. Yale University Press. (2005)

8. J. Auerbach, The Great Exhbition of 1851: A Nation on Display (1999)

9. D. Zhang, An analysis of the thought of human is an integral part of nature in Chinese Philosophy. Journal of Peking University . 1. (1985)

10. J. P. Heap, The Management of Innovation and Design. London, Cassell, (1989).

11. M. Chen, The Art of Zen in Japanese MUJI Packaging Design. Packaging Engineering. 4. 36. (2010)

12. Y. Chen, J. Tang, An Discussion of Globalization and Chinese Culture with Art \& Design. Architecture \& Culture 10. (2010)

13. A.Y. Ling, A Question of "Chineseness": The Chinese Diaspora in Singapore 1819-1950s. Degree of Doctor of Philosophy, University of Stirling. (2001).

14. Y. Yan, Chinese design is a pseudo proposition (2011)

15. D. Raizman, History of modern design: Graphics and products since the industrial revolution. Laurence King Publishing. (2003)
16. M. W. Morris, and L. Kwok, Creativity east and west: Perspectives and parallels. Management and Organization Review. 6. 3. (2010)

17. G. S. Insch, M. J. Brad. The impact of country-oforigin cues on consumer perceptions of product quality: A binational test of the decomposed countryof-origin construct. Journal of Business Research. 57. 3. (2004)

18. X. Liu, Y. Li, F. Feng. Thirty Years of Legal Theory in China's Reform and Opening up: 1978-2008 Law and Social Development. 5. 003. (2008)

19. S. Wang, Critical Study on Chinese Design Education. (2007)

20. C. Zhao, Academy of Arts \& Design, Tsinghua University, research filed trip interview (2015)

21. L. Justice, Product Design Education in China (2011)

22. R. Cox, The Zen arts: An anthropological study of the culture of aesthetic form in Japan, Routledge. (2013)

23. X. Leng, M. Zhang, Shanzhai as a Weak Brand in Contemporary China Marketing. International Journal of China Marketing. 1. 2. (2011)

24. Z. Sheng, Y. Shi, Shanzhai manufacturing - an alternative innovation phenomenon in China. Journal of Science and Technology Policy in China. 1. 1. (2010)

25. R. Tan, Market ecology breeds Chinese cottage culture. (2012)

26. W. Lu, L. Heng, L. Shen,T. Huang, Strengths, weaknesses, opportunities, and threats analysis of Chinese construction companies in the global market. Journal of Management in Engineering. 25. 4. (2009)

27. T. Fernandes, A guide to designing international user interfaces. (1995) 